\title{
Penggunaan Frasa Nomina dalam Surat Kabar Jawa Pos: Kontruksi Frasa Nomina
}

\author{
Rohmad Tri Aditiawan \\ Universitas Muhammadiyah Jember \\ aditiawan11@gmail.com
}

DOI: https://doi.org/10.32528/bb.v5i2.3243

First received: 09-05-2020 Final proof received: 29-09-2020

\begin{abstract}
ABSTRAK
Kontruksi frasa dalam bahasa Indonesia biasanya tersusun dari dua kata atau lebih sebagai anggotanya dan hubungan antara unsur langsungnya bersifat longgar atau terbuka. Selain itu, frasa memiliki fungsi sintaksis artinya, fungsi yang berkaitan dengan kata atau frasa dalam sebuah kalimat yang terdiri dari subjek, predikat, objek, keterangan, dan pelengkap. Penelitian ini bertujuan untuk (1) mendeskripsikan bentukbentuk frasa nominal yang terdapat dalam surat kabar Jawa Pos edisi 3 Desember 2019, (2) mendeskripsikan karakteristik fungsi frasa nominal yang terdapat dalam surat kabar Jawa Pos edisi 3 Desember 2019. Analisis data dilakukan secara deskriptif kualitiatif. Jenis data yang digunakan data kualitatif. Metode analisis data pada penelitian ini dilakukan menggunakan metode agih. Sumber data penelitian ini yaitu data tertulis berupa surat kabar. Teknik pengumpulan data menggunakan baca dan catat. Teknik analisis data dengan mengklasifikasikan teori dan referen frasa nomina. Teknik pengujian keabsahan data dengan mengunakan buku teori, pencocokan kembali data-data juga menggunakan Kamus Besar Bahasa Indonesia. Hasil penelitian adalah bentuk-bentuk dan fungsi frasa nomina dalam surat kabar Jawa Pos edisi 3 Desember 2019 terdiri dari 3 bentuk dan fungsi frasa nomina yang terdiri dari nomina + nomina dengan temuan frasa nomina motor listrik dan rumah tangga yang memiliki kesamaaan menduduki fungsi objek (O), nomina + verba terdapat temuan bahan bakar minyak dan tikus berdasi yang memiliki kesamaan menduduki objek (O), nomina + adjektiva terdapat temuan perguruaan tinggi menduduki subjek (S) dan jangka panjang menduduki keterangan (Ket).
\end{abstract}

Kata kunci : Bentuk; karakteristik fungsi; frasa nomina

\begin{abstract}
The construction of phrases in Indonesian usually consists of two or more members and the relationship between the direct elements is loose or open. In addition, phrases have a syntactic function, which is related to the order of words or phrases in a sentence consisting of subject, predicate, object, description, and complement. This study aims to (1) describe the forms of nominal phrases contained in the December 3, 2019
\end{abstract}


edition of the Jawa Pos newspaper, (2) describe the functions of nominal phrases found in the December 3, 2019 edition of the Jawa Pos newspaper. Data analysis was carried out descriptively qualitative. The type of data used is qualitative data. The method of data analysis in this study was carried out using the agih method. The data source used is written data in the form of newspapers. The data technique uses read and note. Data analysis techniques by classifying theory and reference to noun phrases. The technique of testing the validity of the data using theory books, returning the data also uses the Big Indonesian Dictionary. The results of the research are the forms and functions of noun phrases in the Jawa Pos 3 December 2019 edition consisting of 3 forms and functions of noun phrases consisting of noun + noun with the findings of electric motor and household phrases that have the same object function $(\mathrm{O})$, noun + verb there is a finding of fuel oil and a mouse with a tie that has the content of the object $(\mathrm{O})$, noun + adjective there are findings of the subject's higher education (S) and the length of the description (Ket).

Keywords: Form; function characteristics; noun phrases

\section{PENDAHULUAN}

Frasa adalah susunan dari dua kata atau lebih yang sifatnya tidak predikatif, dan termasuk suatu kajian sintaksis menurut Kridalaksana, (dalam Murdayanti 2014). Sedangangkan menurut Samsuri (2009) frasa adalah satuan terkecil sintaksis yang merupakan pemadu sebuah kalimat. Frasa secara umum yaitu satuan gramatikal yang berupa susunan kata bersifat non-predikatif, selain itu dapat disebut suatu gabungan kata yang mengisi salah satu fungsi sintaksis di dalam kalimat (Chaer, 2009). Sebuah frasa sekurangnya memiliki dua kata pembentuk. Kata pembentuk tersebut ialah sebuah frase yang dekat atau langsung membentuk sebuah frase (Parera, 2009). Sejalan dengan pendapat Permana (2010) Frasa adalah unsur klausa yang tersusun dari dua kata atau lebih dan tidak melampaui batas fungsi pada kalimat yaitu subjek dan predikat atau dengan arti lain frasa adalah satuan gramatikal tersusun dari dua kata atau lebih yang tidak melebihi batas fungsi unsur klausa subjek dan predikat.

Frasa nomina dapat dikatakan frasa modifikatif yang terdiri dari kelas kata nomina sebagai induk atau utama dan unsur sebagai perluasan lain yang memiliki hubungan subordinatif dengan induk kata, yaitu adjektiva, verba, numeralia, demonstrative, pronominal, artikula, frasa preposisi, frasa dengan artikula, frasa preposisi, frasa dengan yang ... nya, atau frasa lain. Frasa nomina yang bertugas sebagai subjek, objek, atau komplemen dalam kontruksi predikatif. Keraf (dalam Ismail 2016) menjelaskan frasa sebagai suatu kesatuan yang tersusun dari dua kata atau lebih dengan mempertahankan makna dasar katanya. Selain itu, gabungan tersebut menghasilkan suatu hubungan tertentu, dan setiap kata bentukannya tidak berfungsi sebagai predikat (P) dalam kontruksi frasa. Menurut Ramlan (dalam Sumadi 2009) Frasa nominal adalah frasa yang memiliki distribusi sama dengan nomina. Persamaan distribusi itu dapat diketahui dari satuan frasa seperti : Ia membeli 'baju baru' dan Ia membeli 'baju'. Frasa 'baju baru' dalam klausa tersebut mempunyai distribusi yang 
sama dengan kata 'baju'. Kata 'baju' termasuk golongan kata nomina, karena itu, frasa 'baju baru' termasuk golongan frasa nomina.

Menurut Sumadi (2009) bentuk frasa nomina diketahui dengan menganalisis kata dasar dengan penambahannya seperti gedung sekolah frasa tersebut adalah frasa nomina dimana nomina pusatnya tereletak pada kata gedung dan ditambahkan sekolah menjadi 'gedung sekolah' yang memiliki makna gramatikal baru yaitu gedung tempat untuk belajar dan mengajar yang terletak di sekolah. Maka dapat diketahui adanya frasa nominal dengan berbagai karakteristik sebagai berikut, seperti 'adik saya', 'sebuah meja' yang mengisi fungsi subjek (S), predikat (P), objek (O) dan pelengkap (Pel), tidak semua frasa dapat menduduki semua fungsi yang menyusun kalimat. Nomina juga dapat berupa bentuk frasa preposisional. Nomina menduduki poros atau inti yang didahului oleh kata depan atau preposisi. Contoh ke 'pasar', dari 'desa', untuk 'kekasih', pada 'hari minggu'. Menurut Wasik (2017) Frasa nominal memiliki ciri khas tersendiri dilihat dari bentuk bentuk frasa nomina dengan makna gramatikal yang baru dan karakteristik untuk mencari variasi frasa nomina dapat ditempatkan pada fungsi subjek $(\mathrm{S})$, fungsi predikat $(\mathrm{P})$, fungsi objek $(\mathrm{O})$, dan fungsi pelengkap (Pel)

Pada penelitian ini peneliti akan menganalisis frasa nominal dalam surat kabar Jawa Pos edisi 3 Desember 2019 untuk mengetahui bentukan frasa nomina yang terdapat pada surat tersebut serta untuk mengetahui variasi frasa nomina dapat difungsikan sebagai subjek (S), predikat $(\mathrm{P})$, objek (O), dan pelengkap (Pel) pada surat kabar tersebut. Jadi berita atau teks yang masuk dalam surat kabar Jawa Pos bukanlah berita atau teks yang sembarangan, dan sudah melalui tahap editing yang cukup panjang. Oleh karena itu, penelitian mengenai frasa nominal dalam ini menarik untuk diteliti karena masih jarang penelitian tentang frasa nominal terhadap surat kabar Jawa Pos.

Pada penelitian sebelumnya oleh Kurniawati (2009) meneliti "Frase Nomina dalam Novel Pasar Karya Kuntowijoyo". Hasil penelitian yang dilakukan Kurniawati yaitu distribusi frasa nomina endosentrik yaitu frasa endosentrik atributif, frasa endosentrik koordinatif, dan frasa endosentrik apositif. Persamaan penelitian ini dengan Kurniawati adalah membahas dan mendeskripsikan tentang bentuk-bentuk frase nomina. Perbedaan penelitian Kurniawati menggunakan objek penelitian berupa novel sedangkan penelitian yang dilakukan peneliti adalah menggunakan objek Surat Kabar Jawa Pos edisi 3 Desember 2019. Situmorang (2010) meneliti "Frasa Nomina Bahasa Batak Toba: Analisis Teori X-Bar". Hasil penelitian yang dilakukan situmorang membahas bahwa struktur internal frasa nomina Bahasa Batak Toba dibentuk oleh specifier, komplemen, dan keterangan. Persamaan dengan penelitian ini adalah mengidentifikasi dan menganalisis penggunaan frase nomina. Perbedaannya penelitian ini membahas tentang karakteristik fungsi dalam frasa nomina sedangkan penelitian Sitomurang membahas tentang struktur internal frasa nomina.

\section{METODE PENELITIAN}

Metode penelitian yang digunakan adalah deskriptif kualitatif, karena penelitian ini mendeskripsikan suatu objek yang diteliti yaitu bentuk-bentuk dan karakteristik 
fungsi frasa nomina yang terdapat dalam surat kabar Jawa Pos edisi 3 Desember 2019. Data kualitatif, data yang disajikan berupa bentuk kata verbal bukan bentuk angka. Data kualitatif pada penelitian ini menjabarkan bentuk-bentuk frasa nomina dan karakteristik fungsi frasa nomina dalam surat kabar Jawa Pos edisi 3 Desember 2019. Data tersebut dianalisis dengan menggunakan metode agih. Metode agih merupakan sebuah metode yang berpedoman penentunya yaitu bagian dari bahasa itu sendiri (Sudaryanto, 1993). Peneliti membahas tentang deskripsi frasa nomina yang berhubungan bentuk dan karakteristik fungsi frasa nomina. Menurut Siswantoro (2014) Sumber data terkait dengan subjek penelitian darimana sebuah data diperoleh. Sumber data adalah siapa dan apa yang menjadi tolak ukur sumber informasi dalam suatu penelitian. Sumber data pada penelitian ini adalah data tertulis dalam surat kabar Jawa Pos edisi 3 Desember 2019 yang berupa bentuk-bentuk dan karakteristik fungsi frasa nomina.

Pada pengumpulan data, peneliti mencari surat kabar Jawa Pos edisi 3 Desember 2019. Pengumpulan data pada penelitian ini yaitu dengan menggunakan teknik baca dan catat. Menurut Mahsun (2012) Jika peneliti menemukan dengan penggunaan bahasa dalam bentuk tertulis, maka dalam proses penyadapan peneliti hanya menggunakan teknik catat, dengan mencatat beberapa bentuk yang relevan bagi penelitian dari penggunaan bahasa secara tertulis tersebut. Penggunaan teknik baca efektif karena cara yang digunakan untuk memperoleh data penelitian dilakukan dengan membaca penggunaan bahasa. Teknik catat dilakukan untuk mencatat keseluruhan data yang ditemukan berupa frasa nominal dalam surat kabar Jawa Pos tersebut. Teknik ini dilakukan dengan mencatat data yang diperoleh kemudian ditulis pada kertas data.

Instrumen utama pada penelitian ini adalah peneliti sendiri (human instrument). Pada penelitian ini pengetahuan peneliti tentang kebahasaan menjadi alat pengumpul data yang utama (Moleong, 2011). Instrumen yang dipergunakan untuk menjaring data pada penelitian ini adalah kriteria yang terdapat dalam pemikiran peneliti. Kriteria tersebut adalah kriteria bentuk-betuk dan karakteristik fungsi frasa nomina.

Analisis data penelitian dilakukan dengan mengidentifikasi frasa nomina berdasarkan bentuk yang ditemukan dalam surat kabar Jawa Pos edisi 3 Desember 2019, setelah itu akan dilakukan dengan mengklasifikasikan berdasarkan teori atau referen tentang frasa nomina, serta dilanjutkan dengan analisis dan penarikan kesimpulan.

Penelitian ini menggunakan triangulasi yang memanfaatkan teori, yaitu pengecekan dengan menggunakan buku-buku teori sintaksis. Data yang didapat dari sumber data berupa bentuk frasa nomina. Setelah data tersebut terkumpul maka selanjutnya akan dilakukan triangulasi atau pengecekan pada data tersebut. Triangulasi dengan buku-buku teori dilakukan dengan mencocokan kembali apakah data-data yang diambil telah sesuai atau memenuhi syarat sebuah frasa. Teori-teori yang diungkapkan para ahli akan menjadi acuan apakah sumber data sudah valid atau tidak. Selain mengunakan buku teori, pencocokan kembali data-data juga menggunakan Kamus Besar Bahasa Indonesia. 


\section{HASIL DAN PEMBAHASAN}

Frasa tersusun dari dua kata atau lebih yang dapat membentuk makna gramatikal berkaitan atau makna gramatikal baru. Dalam surat kabar Jawa Pos terdapat beberapa Frasa nomina yang dapat berupa gabungan bentuk dari kata nomina dengan nomina, nomina dengan verba, dan nomina dengan adjektiva yang bertujuan untuk menemukan bentuk dan karakterisik fungsi frasa nomina dalam surat kabar Jawa Pos.

\section{Frasa Nomina + Nomina}

Pada surat kabar Jawa Pos ditemukan beberapa kalimat yang mengandung frasa nomina. Frasa nomina terbentuk karena kata pusatnya yaitu kelas kata nomina (benda) dan dapat didistribusikan dengan kelas kata nomina lainnya sehingga dapat membentuk makna gramatikal yang berkaitan maupun makna gramatikal yang baru seperti contoh berikut.

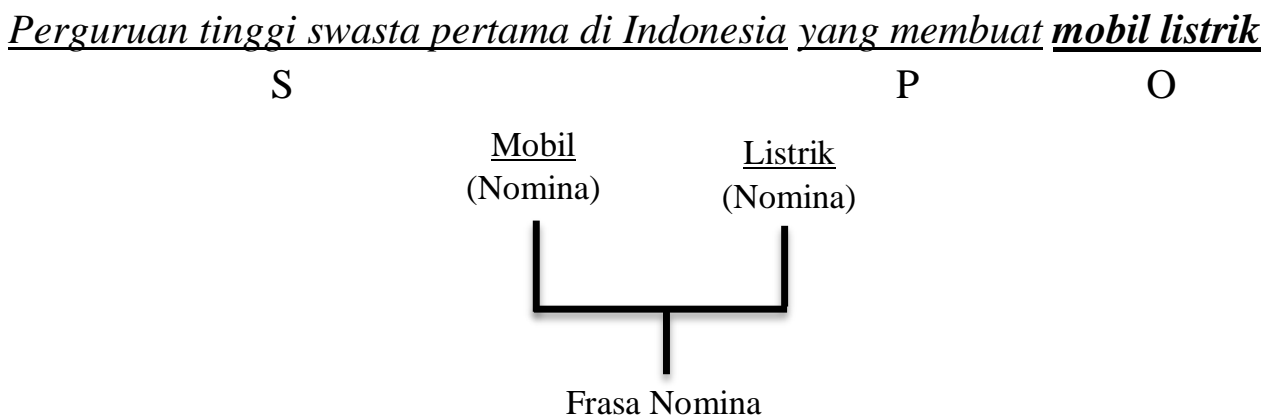

Kata Mobil Listrik termasuk pada frasa nomina disebabkan karena kata mobil dan kata listrik termasuk kelas kata nomina. Kelas kata nomina diklasifikasikan sebagai kelas kata terbuka disebabkan nomina yaitu kelas yang anggotanya dapat bertambah dan berkurang sewaktu-waktu dilihat dari perkembangan sosial budaya yang terjadi pada masyarakat penutur suatu bahasa. Kata Mobil Listrik dikatakan frasa nomina karena terdiri dua kata yang termasuk kata nomina + nomina yaitu Mobil + Listrik. Makna leksikal dari kata Mobil yaitu kendaraan beroda 4 yang digerakkan oleh mesin, sedangkan Listrik memiliki makna daya, kekuatan yang ditimbulkan oleh proses gesekan proses kimia. Selain itu, makna gramatikal yang berkaitan dari Mobil Listrik yaitu Mobil yang digerakkan oleh motor atau mesin listrik, menggunakan listrik.

Selain itu, Frasa nomina mobil listrik menduduki fungsi sebagai objek terlihat pada analisis kalimat Karakeristik kalimat peruruan tinggsi swasta pertama di indonesia manduduki subjek (S), yang membuat menduduki predikat (P), dan mobil listrik menduduki objek $(\mathrm{O})$. Dikatakan frasa nomina karena ciri-ciri dari frasa nomina yaitu karena mobil dan listrik termasuk kelas kata benda (nomina). Sehingga frasa nomina Mobil listrik dalam kalimat tersebut berfungsi sebagai objek (O) pengisi predikat.

Berbeda dengan kalimat Indonesia mencatat tindak kekerasan rumah tangga pada 2019 menngkat. Pada kata Rumah Tangga termasuk frasa nomina namun membentuk makna gramatikal baru dengan gabungan dari kata nomina serta menduduki frasa nomina sebagai objek seperti pada berikut ini. 


\section{Indonesia mencatat tindak kekerasan rumah tangga pada 2019 meningkat}

$\mathrm{S}$

$\mathrm{P}$

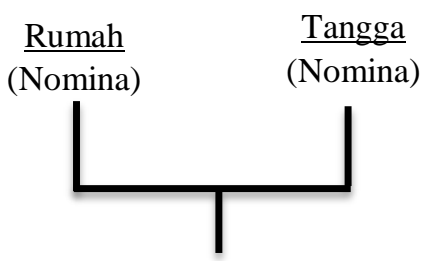

Frasa Nomina

Pel

Kata Rumah Tangga termasuk frasa nomina karena terdiri dari dua kata yang memiliki kesamaan kelas kata nomina. Kelas kata nomina diklasifikasikan sebagai kelas kata terbuka disebabkan nomina yaitu kelas yang anggotanya dapat bertambah dan berkurang sewaktu-waktu dilihat dari perkembangan sosial budaya yang terjadi pada masyarakat penutur suatu bahasa. Kata rumah tangga dikatakan frasa nomina karena terdiri dua kata yang memiliki kesamaan termasuk dalam kelas kata nomina + nomina yaitu Rumah + Tangga. Makna Leksikal dari kata Rumah yaitu bangunan untuk tempat tinggal, sedangkan angga memiliki makna tumpuan untuk naik turun dibuat dari kayu (papan, batu, dan sebagainya) bersusun berlenggek-lenggek. Namun makna gramatikalnya tidak ada kaitan dengan makna leksikalnya dan membentuk makna gramatikal baru yaitu Hal yang berkenaan dengan urusan kehidupan rumah (seperti hal belanja rumah) dan keluarga.

Selain itu, Frasa nomina rumah tangga menduduki fungsi sebagai objek terlihat pada analisis kalimat Karakeristik pada data kalimat, indonesia manduduki subjek (S), mencatat kekerasan menduduki predikat (P), dan dalam rumah tangga menduduki objek (O), pada 2019 meningkat menduduki pelengkap (Pel). Dikatakan frasa nomina karena ciri-ciri dari frasa nomina yaitu karena Rumah dan Tangga termasuk kelas kata benda (nomina). Sehingga frasa nomina Rumah Tangga dalam kalimat tersebut berfungsi sebagai objek $(\mathrm{O})$ pengisi predikat.

\section{Frasa Nomina + Verba}

Frasa nomina dapat terjadi jika kata pusatnya termasuk kelas kata nomina (benda) dan didistribusikan dengan kelas kata verba (kerja), sehingga dapat membentuk makna gramatikal yang berkaitan maupun makna gramatikal yang baru dan memiliki karateristik fungsi sebagai frasa nomina.

\section{Mobil listrik ini dibuat untuk menghemat bahan bakar minyak}

$S$

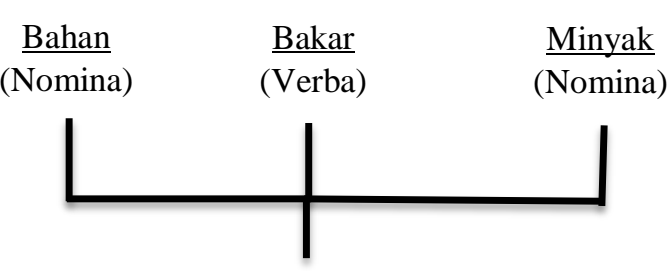

$P$

$O$

Frasa Nomina 
Kata Bahan Bakar Minyak termasuk frasa nomina karena terdiri dua kata yang yang terdiri dari Bahan (Nomina), Bakar (verba) dan Minyak (Nomina). Kelas kata nomina dan verba diklasifikasikan sebagai kelas kata terbuka disebabkan nomina dan verba yaitu kelas kata yang keanggotaanya dapat bertambah dan berkurang sewaktuwaktu dilihat dengan perkembangan sosial budaya yang terjadi pada masyarakat penutur suatu bahasa. Kata bahan bakar dikatakan frasa nomina karena terdiri dari dua kata yang masing-masing termasuk dalam kelas kata nomina + verba + nomina yaitu Bahan + Bakar + Minyak. Makna Leksikal dari kata Bahan yaitu sesuatu yang dapat dipakai atau diperlukan untuk tujuan tertentu, seperti untuk pedoman atau pegangan, untuk mengajar, memberi ceramah, sesuatu yang menjadi sebab (pangkal) atau sikap (perbuatan), sedangkan bakar memiliki makna panggang, sedangkan minyak bermakna zat cair berlemak, biasanya kental, tidak dapat larut dalam air, larut dalam eter dan alkohol, mudah terbakar. Sehingga, makna gramatikalnya berkaitan dengan makna leksikalnya yaitu bahan atau barang yang dipakai untuk menimbulkan api (panas), seperti minyak.

Selain itu, Frasa nomina Bahan bakar minyak menduduki fungsi sebagai objek terlihat pada analisis kalimat Karakeristik pada data kalimat, Mobil listrik ini menduduki subjek (S), dibuat unuk menghemat menduduki predikat $(\mathrm{P})$, dan bahan bakar minyak menduduki objek (O). Dikatakan frasa nomina karena ciri-ciri dari frasa nomina yaitu karena Bahan termasuk kata pusatnya yaitu kata benda (nomina), bakar termasuk kata kerja (verba) dan Minyak termasuk kelas kata benda (nomina). Sehingga frasa nomina Tikus Berdasi dalam kalimat tersebut berfungsi sebagai objek (O) pengisi predikat.

Berbeda dengan kalimat Sangat disayangkan karena ulah tikus berdasi sangat merugikan negara. Pada kata tikus berdasi termasuk frasa nomina namun memiliki makna gramatikal baru dengan gabungan dari kata verba serta memiliki fungsi karakteristik frasa nomina seperti pada berikut ini.

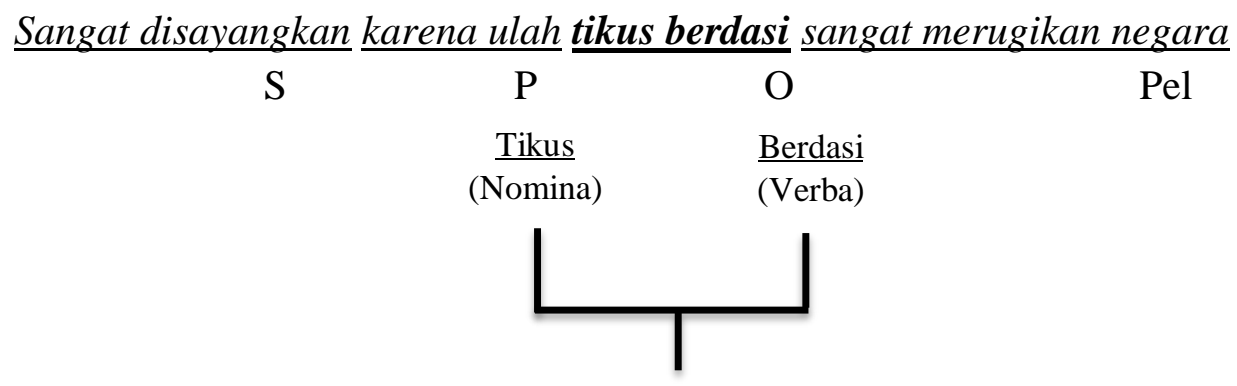

Frasa Nomina

Kata Tikus Berdasi termasuk frasa nomina karena terdiri dua kata yang yang terdiri dari Tikus (Nomina) dan Berdasi (verba). Kelas kata nomina dan verba diklasifikasikan sebagai kelas kata terbuka disebabkan nomina dan verba yaitu kelas kata yang keanggotaanya dapat bertambah dan berkurang sewaktu-waktu dilihat dengan perkembangan sosial budaya yang terjadi pada masyarakat penutur suatu bahasa. Kata 
tikus berdasi dikatakan frasa nomina karena terdiri dua kata yang masing-masing termasuk dalam kelas kata nomina + verba yaitu Tikus + Berdasi. Makna Leksikal dari kata Tikus yaitu binatang pengerat, merupakan hama yang merugikan baik di rumah maupun di sawah, memiliki ciri berbulu, berekor panjang, pada rahangnya terdapat sepasang gigi seri berbentuk pahat dan umumnya berwarna hitam atau kelab, sedangkan berdasi memiliki makna menggunakan dasi. Namun makna gramatikalnya tidak ada kaitan dengan makna leksikalnya dan membentuk makna gramatikal baru yaitu Seseorang yang memakan uang rakyat (Koruptor)

Selain itu, Frasa nomina Tikus Berdasi menduduki fungsi sebagai objek terlihat pada analisis kalimat Karakeristik pada data kalimat, Sangat disayangkan menduduki subjek (S), karena ulah menduduki predikat (P), dan tikus berdasi menduduki objek $(\mathrm{O})$, sangat merugikan negara menduduki pelengkap (Pel). Dikatakan frasa nomina karena ciri-ciri dari frasa nomina yaitu karena tikus termasuk kata pusatnya yaitu kata benda (nomina) dan berdasi termasuk kata kerja (verba). Sehingga frasa nomina Tikus Berdasi dalam kalimat tersebut berfungsi sebagai objek $(\mathrm{O})$ pengisi predikat.

\section{Frasa Nomina + Adjektiva}

Pada surat kabar Jawa Pos terdapat beberapa frasa nomina. Frasa nomina dapat terjadi jika kata pusatnya termasuk kelas kata nomina (benda) dan didistribusikan dengan kelas kata adjektiva (sifat), sehingga dapat membentuk makna gramatikal yang berkaitan maupun makna gramatikal yang baru dan memiliki karateristik fungsi sebagai frasa nomina.

Perguruan tinggi yang membuat mobil listrik ternyata berasal dari swasta $\mathrm{S}$ $\mathrm{P}$ $\mathrm{O}$ Pel

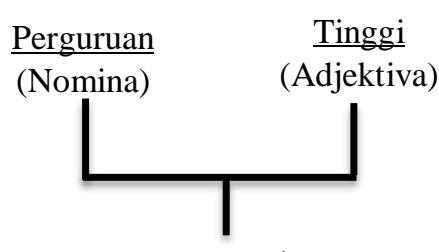

Frasa Nomina

Kata Perguruan Tinggi termasuk pada frasa nomina disebabkan karena kata perguruan termasuk kelas kata nomina dan kata Tinggi termasuk kelas kata adjektiva. Kelas kata nomina diklasifikasikan sebagai kelas kata terbuka disebabkan nomina yaitu kelas kata yang keanggotaanya dapat bertambah dan berkurang sewaktu-waktu dilihat dengan perkembangan sosial budaya yang terjadi pada masyarakat penutur suatu bahasa. Kata Perguruan Tinggi dikatakan frasa nomina karena terdiri dua kata yang termasuk kata nomina + adjektiva yaitu Perguruan + Tinggi. Makna leksikal dari kata Perguruan yaitu sekolah/gedung tempat belajar, sedangkan Tinggi memiliki makna jauh jaraknya dari bawah. Sehingga, makna gramatikal yang berkaitan dari Perguruan Tinggi yaitu tempat pendidikan dan pengajaran tingkat tinggi (universitas). 
Selain itu, Frasa nomina Perguruan Tinggi menduduki fungsi sebagai subjek (S) terlihat pada analisis kalimat Karakeristik kalimat perguruan tinggi menduduki subjek (S), yang membuat menduduki predikat (P), mobil listrik menduduki objek (O), dan ternyata bersal dari swasta menduduki pelengkap (Pel). Dikatakan frasa nomina karena ciri-ciri dari frasa nomina yaitu karena kata perguruan sebagai kata pusatnya termasuk kelas kata benda (nomina). Sehingga frasa nomina Perguruan Tinggi dalam kalimat tersebut berfungsi sebagai subjek (S) karena terdapat diawal kalimat.

Berbeda dengan kalimat Defni mengungkapkan GBHN tidak diperlukan pemerintah karena ada pembangunan jangka panjang. Pada kalimat tersebut terdapat frasa nomina jangka panjang, namun memiliki makna gramatikal yang baru serta menduduki fungsi frasa nomina sebagai keterangan sebagai berikut.

\section{Defni mengungkapkan GBHN tidak diperlukan pemerintah $\underline{\text { karena ada pembangunan }}$ $\mathrm{S}$ $\mathrm{P}$ $\mathrm{O}$} $\frac{\text { jangka panjang }}{\mathrm{K}}$

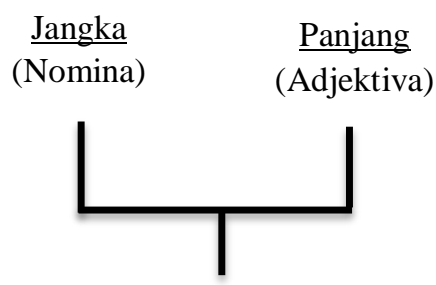

Frasa Nomina

Kata Jangka Panjang termasuk pada frasa nomina disebabkan karena kata Jangka termasuk kelas kata nomina dan kata Panjang termasuk kelas kata adjektiva. Kelas kata nomina diklasifikasikan sebagai kelas kata terbuka disebabkan nomina yaitu kelas yang keanggotaanya dapat bertambah dan berkurang sewaktu-waktu dilihat dengan perkembangan sosial budaya yang terjadi dalam masyarakat penutur suatu bahasa. Kata Jangka Panjang dikatakan frasa nomina karena terdiri dari dua kata yang termasuk kata nomina + adjektiva yaitu Jangka + Panjang. Makna leksikal dari kata Jangka yaitu alat untuk membuat bulatan (lingkaran, mengukur jarak pada peta, dan sebagainya), berupa benda yang berkaki dua yang dapat dilebarkan dan disempitkan langkahnya atau ukurannya, sedangkan Panjang memiliki makna berjarak jauh (dari ujung ke ujung). Selain itu, makna gramatikal yang tidak berkaitan dengan makna leksikalnya, Jangka Panjang yaitu Waktu yang cukup lama.

Selain itu, Frasa nomina Jangka Panjang menduduki fungsi sebagai Keterangan (Ket) terlihat pada analisis kalimat Karakeristik kalimat Defni menduduki subjek (S), Mengungkapkan GBHN tidak diperlukan pemerintah menduduki predikat (P), karena ada pembangunan menduduki objek (O), dan Jangka Panjang menduduki Keterangan (Ket). Dikatakan frasa nomina karena ciri-ciri dari frasa nomina yaitu karena kata Jangka Panjang sebagai kata pusatnya termasuk kelas kata benda (nomina). Sehingga 
frasa nomina Jangka Panjang dalam kalimat tersebut berfungsi sebagai Keterangan (Ket) sebagai unsur kalimat yang memberi keterangan waktu kepada seluruh kalimat.

\section{SIMPULAN}

Berdasarkan analisis penelitian dapat disimpulkan terdapat banyak bentuk frasa nomina, dan juga fungsi karakteristik frasa nomina yang terdapat pada surat kabar Jawa Pos edisi 3 Desember 2019. Frasa sebagai kesatuan yang terdiri dua kata atau lebih yang mempertahankan makna dasar katanya, selain itu, gabungan itu menghasilkan suatu relasi tertentu. Kontruksi frasa dalam bahasa Indonesia biasanya terdiri atas dua atau lebih sebagai anggotanya dan hubungan antara unsur langsungnya bersifat longgar atau terbuka. Selain itu, frasa memiliki fungsi bersifat sintaksis artinya berkaitan dengan urutan kata atau frasa dalam kalimat terdiri dari subjek (S), predikat $(\mathrm{P})$, objek $(\mathrm{O})$, keterangan (Ket), dan pelengkap (Pel).

Pada bentuk-bentuk frasa nomina ditemukan 3 bentuk yaitu nomina + nomina, nomina + verba, dan nomina + adjektiva serta dapat ditentkan fungsi karakteristik frasa nomina pada kalimat terdapat Subjek, Objek, dan Keterangan. Pada bentuk nomina + nomina ditemukan frasa nomina mobil listrik menduduki fungsi objek (O) memiliki makna gramatikal mobil yang digerakkan oleh motor atau mesin listrik, menggunakan listrik dan frasa nomina rumah tangga menduduki fungsi objek $(\mathrm{O})$ memiliki makna gramatikal baru yaitu berkenaan urusan kehidupan rumah (seperti hal belanja rumah) dan keluarga. Pada bentuk nomina + verba ditemukan frasa nomina bahan bakar minyak menduduki fungsi objek (O) bermakna gramatikalnya berkaitan dengan makna leksikalnya yaitu bahan atau barang yang dipakai untuk menimbulkan api (panas), seperti minyak dan frasa nomina tikus berdasi menduduki fugsi objek (O) bermakna gramatikalnya tidak ada kaitan dengan makna leksikalnya dan membentuk makna gramatikal baru yaitu seseorang yang memakan uang rakyat (Koruptor). Pada bentuk nomina + adjektiva ditemukan frasa nomina peruruan tinggi menduduki fungsi subjek (S) makna gramatikal yang berkaitan yaitu tempat pendidikan dan pengajaran tingkat tinggi (universitas) dan frasa nomina jangka panjang menduduki fungsi keterangan (Ket) memiliki makna gramatikal yang tidak berkaitan dengan makna leksikalnya yaitu waktu yang cukup lama.

\section{DAFTAR RUJUKAN}

Chaer, A. (2009). Sintaksis Bahasa Indonesia: Pendekatan Proses. Jakarta: Rineka Cipta.

Ismail, M.M. (2016). Penggunaan Frasa Nominal Pada Rubrik Cerpen Koran Kompas Bulan Juni - Agustus 2014. Yogyakarta: Universitas Negeri Yogyakarta.

Jawa Pos. (2019). Edisi 3 Desember 2019. Surabaya.

Kurniawati, S. (2009). Frase Nomina dalam Novel Pasar Karya Kuntowijoyo. Yogyakarta. Universitas Ahmad dahlan. 
Mahsun. (2012). Metode Penelitian Bahasa Tahapan Strategi, Metode, dan Tekniknya. Depok: PT Rajagrafindo Persada.

Murdayanti, N. (2014). Kajian Frasa Nomina Beratribrut Pada Teks Terjemahan Al Quran Surat Al-Ahzab. Surakarta: Universitas Muhammadiyah Surakarta

Moleong, L.J. (2011). Metodologi Penelitian Kualitatif. Bandung. Remaja Rosdakarya.

Parera, J.D. (2009). Dasar-dasar Analisis Sintaksis. Jakarta: Erlangga.

Permana, D. (2010). Fasa Nomina dalam Bahasa Banjar Samarinda. Jurnal Eksis. 6 (1): 1267-1266.

Samsuri. (1982). Analisis Bahasa. Malang: Erlangga.

Siswantoro. (2014). Metode Penelitian Sastra. Yogyakarta: Pustaka Pelajar.

Situmorang, N.S. (2010). Frasa Nomina Bahasa Batak Toba: Analisis Teori X-Bar. Jurusan Departemen Sastra Indonesia. Fakultas Sastra. Universitas Sumatera Barat.

Sudaryanto, (1993). Metode dan Aneka Teknik Analisis Data. Yogyakarta: Duta Wacana University Press.

Sumadi. (2009). Sintaksis Bahasa Indonesia. Malang: 3A (Asih Asah Asuh)

Wasik, A.H. (2015). Penggunaan Nomina Dalam Surat Kabar Harian Tribun. Yogyakarta: Universitas Sarjanawiyata Tamansiswa Yogyakarta. 
